\title{
SPINT1 Gene
}

National Cancer Institute

\section{Source}

National Cancer Institute. SPINT1 Gene. NCI Thesaurus. Code C107610.

This gene plays a role in the regulation of hepatocyte growth factor maturation. 